Asymmet ri c het ero di el s- al der react i on of ni troso compounds utilizing tartaric acid ester as a chiral auxiliary

\begin{tabular}{|c|c|}
\hline 著者 & $\begin{array}{l}\text { Sakai Hi r oki, Di ng Xi a, Yoshi da Tet susuke, } \\
\text { Fuj i nam Shuhei, Ukaj i Yut aka, I nomat a } \\
\text { Kat suhi ko }\end{array}$ \\
\hline 著者別表示 & 藤波 修平，宇梶 裕，猪股 勝彦 \\
\hline $\begin{array}{l}\text { j our nal or } \\
\text { publ i cat i on titl e }\end{array}$ & Het er ocycl es \\
\hline vol une & 76 \\
\hline nunber & 2 \\
\hline page $r$ ange & $1285-1300$ \\
\hline year & 2008-11- 01 \\
\hline URL & ht t p: //doi . or g/10. 24517/00010931 \\
\hline
\end{tabular}




\title{
ASYMMETRIC HETERO DIELS-ALDER REACTION OF NITROSO COMPOUNDS UTILIZING TARTARIC ACID ESTER AS A CHIRAL AUXILIARY
}

\author{
Hiroki Sakai, Xia Ding, Tetsusuke Yoshida, Shuhei Fujinami, Yutaka \\ Ukaji,* and Katsuhiko Inomata*
}

Division of Material Sciences, Graduate School of Natural Science and Technology, Kanazawa University, Kakuma, Kanazawa, Ishikawa 920-1192, inomata@cacheibm.s.kanazawa-u.ac.jp

\begin{abstract}
The regio- and enantioselective hetero Diels-Alder reaction of a nitroso compound with a cyclic dienol, cyclohexa-1,3-dienylmethanol, has been realized utilizing stoichiometric amount of tartaric acid ester as a chiral auxiliary to afford the corresponding dihydro-1,2-oxazine with complete regioselectivity and high enantioselectivity of up to $92 \%$ ee. A catalytic version of the asymmetric hetero Diels-Alder reaction of nitroso compounds with the dienol was also achieved to afford the corresponding optically active cycloadducts with up to $83 \%$ ee. The addition of MS 4A was crucial to realize reproducible high enantioselectivity.
\end{abstract}

\section{INTRODUCTION}

The hetero Diels-Alder reaction provides a very convenient approach to the synthesis of six-membered partially saturated heterocycles, a class of compounds that have been found extensive use as starting materials for total syntheses of natural products. ${ }^{1}$ A wide range of nitroso compounds have been proven to be useful dienophiles for the hetero Diels-Alder reaction to afford dihydro-1,2-oxazine derivatives, which are key intermediates for the synthesis of biologically active nitrogen-containing chemicals. Development of asymmetric hetero Diels-Alder reaction of nitroso compounds was for a long time restricted to only diastereoselective reactions using chiral dienes or chiral nitroso compounds in spite of the great potential of the synthetic methodology. ${ }^{2.3}$ Very recently catalytic hetero Diels-Alder reactions of nitroso compounds catalyzed by chiral metal complexes were reported. ${ }^{4-8}$ 
A novel chiral multinucleating system utilizing tartaric acid ester as a chiral auxiliary was developed in our laboratory and it has been successfully applied to the asymmetric 1,3-dipolar cycloaddition reaction. ${ }^{9}$ The promising results obtained from the 1,3-dipolar cycloaddition tempted us to apply this strategy for the enantioselective hetero Diels-Alder reaction of nitroso compound by the use of tartaric acid ester as a chiral auxiliary. When a dienol is successively treated with diisopropylzinc, a stoichiometric amount of diisopropyl $(R, R)$-tartrate $[(R, R)$-DIPT], propylzinc bromide, zinc-bridging intermediate would be presumably formed. To the intermediate is added a nitroso compound, it can be activated and well oriented as depicted as A in Eq. 1. The subsequent hetero Diels-Alder reaction is anticipated to proceed to give the corresponding dihydro-1,2-oxazine derivatives in an enantioselective manner. ${ }^{10}$ Based upon this hypothesis, the hetero Diels-Alder reaction was examined. ${ }^{11}$

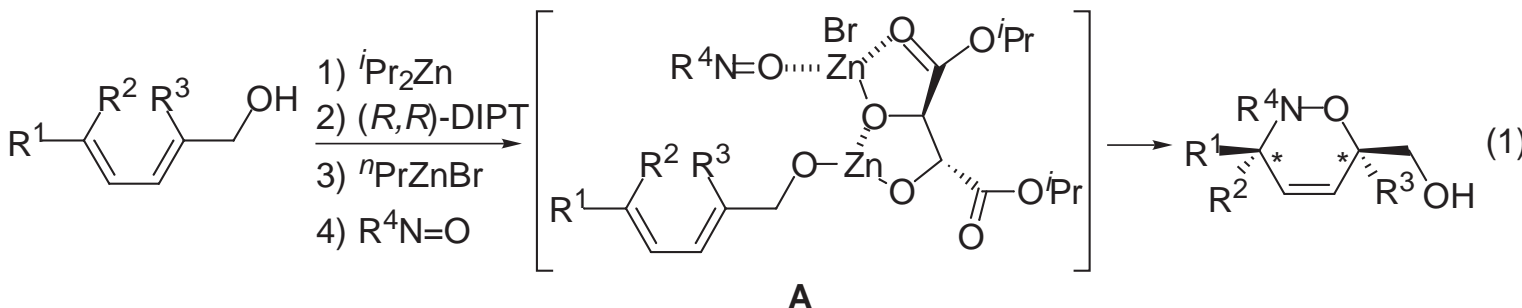

\section{RESULTS AND DISCUSSION}

First, the enantioselective hetero Diels-Alder reaction of nitrosobenzene (2a) to $(E)$-2,4-pentadien-1-ol (1A) was examined (Eq. 2, $\mathrm{R}=\mathrm{H}$ ). When $\mathbf{1 A}$ was treated with 1.0 equivalent of diisopropylzinc, $(R, R)$ DIPT, propylzinc bromide, and 2a successively, the corresponding dihydro-1,2-oxazine derivative was obtained as a mixture of regioisomers $\mathbf{3 A}$ and $\mathbf{4 A}$ with different $\mathrm{N}-\mathrm{O}$ orientation in favor of $\mathbf{3 A}$, in which oxygen of the nitroso group oriented toward the diene carbon bearing $\mathrm{CH}_{2} \mathrm{OH}$ moiety. The enantioselectivity of the major product $\mathbf{3 A}$ was $33 \%$ ee. The hetero Diels-Alder reaction to $(E, E)-2,4-$ hexadien-1-ol (1B) was also examined to give 3B with the enantioselectivity of $55 \%$ ee along with the regioisomer 4B (Eq. 2, $\mathrm{R}=\mathrm{Me}$ ). This modest enantioselectivity encouraged us to further investigate the reaction.

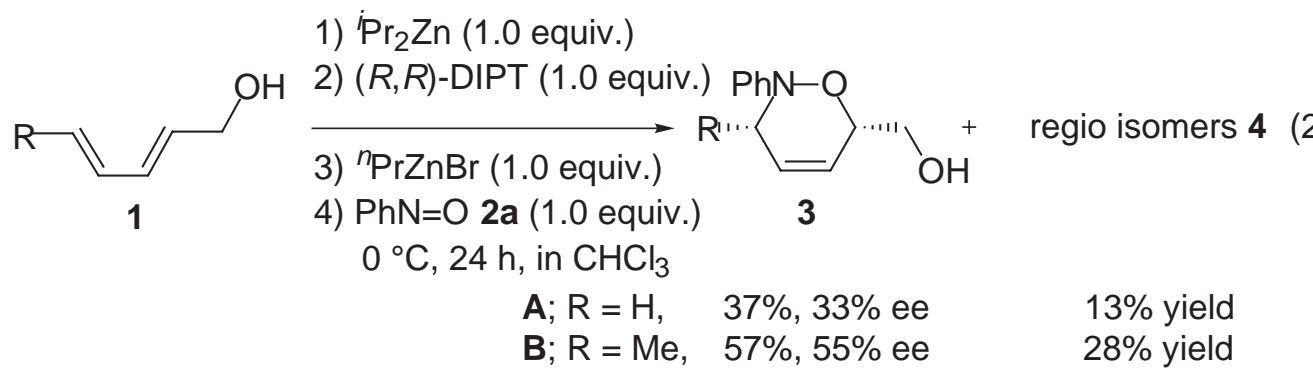

When cyclohexa-1,3-dienylmethanol (5) was used as a diene component as shown in Eq. 3, we were pleased to find that the reaction proceeded in complete regioselective manner to afford the corresponding 
bicyclic dihydro-1,2-oxazine $6 \mathbf{a}$ as a sole product with enantioselectivity of $63 \%$ ee. To our surprise, the sense of enantiofacial discrimination of $\mathbf{5}$ was opposite to that in the case of $\mathbf{1}$, that is, nitrosobenzene (2a) attacked from $r e$-face at the $\mathrm{C} 1$ position of $\mathbf{5}$, while the reaction occurred from si-face at the $\mathrm{C} 2$ position of $\mathbf{1}$, as will be described later. ${ }^{12}$

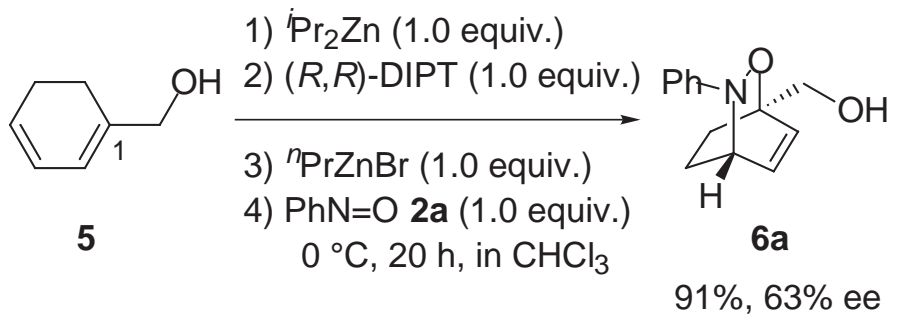

A number of conditions have been attempted to improve the chemical yield and selectivity of the present hetero Diels-Alder reaction. An alternative procedure by successive treatment of $(R, R)$-DIPT with propylzinc bromide and diisopropylzinc, followed by addition of the dienol $\mathbf{5}$ and nitrosobenzene (2a) was tried as shown in Eq. 4. The effects of solvent and chiral auxiliary were also examined as listed in Table 1. It was found that enantioselectivity of the cycloadduct $\mathbf{6 a}$ was remarkably influenced by the solvent employed. The good chemical yields were observed in halocarbon solvents and toluene (Entries 1-3). The highest optical yield was attained in diethyl ether when $(R, R)$-DIPT was used as a chiral auxiliary (Entry 8). Optimization of chemical yield and enantioselectivity was attempted with other tartrates as the chiral auxiliary. The use of bulky di(t-butyl) $(R, R)$-tartrate $[(R, R)$-DTBT] increased enantioselectivity of the corresponding cycloadduct 6a up to $88 \%$ ee in $76 \%$ yield in diethyl ether (Entry 14). Moreover, cycloadduct 6 a was obtained with more than $91 \%$ ee when diethyl ether was replaced by $t$-butyl methyl ether as a solvent, though the chemical yield decreased a little (Entry 15). It was reported that dimerization of nitrosobenzene (2a) strongly depends on the concentration of the solution; the monomer predominantly exists in dilute solution. ${ }^{13}$ Dilution of the reaction mixture was thus expected to be effective to suppress the undesirable dimerization of nitrosobenzene (2a). Therefore, the reaction was performed under the dilute conditions using $t$-butyl methyl ether as a solvent. Under the dilute conditions, the reaction was conducted on a $0.5 \mathrm{mmol}$ scale in $18 \mathrm{~mL}$ of $t$-butyl methyl ether as a solvent. Gratifyingly, the chemical yield was remarkably increased from 56\% to $73 \%$ with high enantioselectivity (Entry 16). Furthermore, it was found that the slow charge of excess amount of solid nitrosobenzene (2a) was remarkably effective: when 1.5 equivalents of solid 2a was added to the reaction mixture over a period of $3 \mathrm{~h}$, the chemical yield was improved to $94 \%$ with excellent enantioselectivity of up to $92 \%$ ee (Entry 17). 


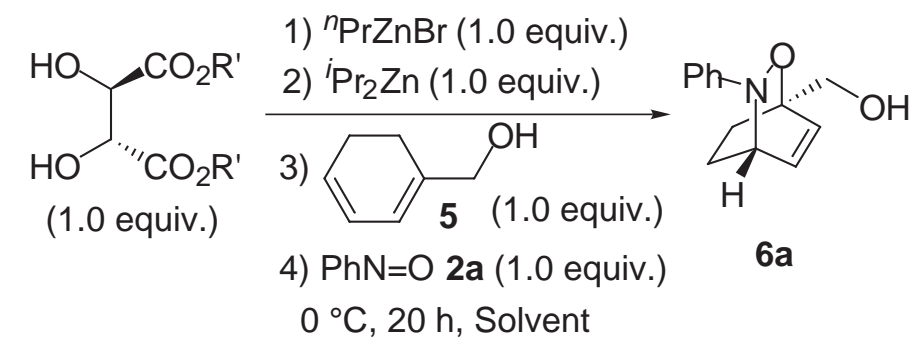

Table 1. The effects of solvent and chiral auxiliary ${ }^{\mathrm{a}}$

\begin{tabular}{|c|c|c|c|c|}
\hline Entry & $\mathrm{R}^{\prime}$ & Solvent & Yield/\% & ee $/ \%^{b}$ \\
\hline 1 & ${ }^{i} \mathrm{Pr}$ & $\mathrm{CHCl}_{3}$ & 86 & 72 \\
\hline 2 & ${ }^{i} \operatorname{Pr}$ & $\mathrm{CH}_{2} \mathrm{Cl}_{2}$ & 80 & 74 \\
\hline 3 & ${ }^{i} \mathrm{Pr}$ & toluene & 82 & 69 \\
\hline 4 & ${ }^{i} \operatorname{Pr}$ & ${ }^{i} \mathrm{Pr}_{2} \mathrm{O}$ & 51 & 64 \\
\hline 5 & ${ }^{i} \operatorname{Pr}$ & THF & 18 & 57 \\
\hline 6 & ${ }^{i} \operatorname{Pr}$ & DME & 64 & 20 \\
\hline 7 & ${ }^{i} \operatorname{Pr}$ & $\mathrm{CH}_{3} \mathrm{CN}$ & 64 & 37 \\
\hline 8 & ${ }^{i} \mathrm{Pr}$ & $\mathrm{Et}_{2} \mathrm{O}$ & 69 & 77 \\
\hline 9 & $\mathrm{Et}$ & $\mathrm{Et}_{2} \mathrm{O}$ & 43 & 60 \\
\hline 10 & $\mathrm{Bn}$ & $\mathrm{Et}_{2} \mathrm{O}$ & 17 & 11 \\
\hline 11 & & $\mathrm{Et}_{2} \mathrm{O}$ & 83 & 46 \\
\hline 12 & & $\mathrm{Et}_{2} \mathrm{O}$ & 67 & 67 \\
\hline 13 & & $\mathrm{Et}_{2} \mathrm{O}$ & 69 & 70 \\
\hline 14 & ${ }^{t} \mathrm{Bu}$ & $\mathrm{Et}_{2} \mathrm{O}$ & 76 & 88 \\
\hline 15 & ${ }^{t} \mathrm{Bu}$ & ${ }^{t} \mathrm{BuOMe}$ & 56 & 91 \\
\hline $16^{c}$ & ${ }^{t} \mathrm{Bu}$ & ${ }^{t} \mathrm{BuOMe}$ & 73 & 89 \\
\hline $17^{\mathrm{c}, \mathrm{d}}$ & ${ }^{t} \mathrm{Bu}$ & ${ }^{t} \mathrm{BuOMe}$ & 94 & 92 \\
\hline $18^{\mathrm{c}, \mathrm{e}}$ & ${ }^{t} \mathrm{Bu}$ & ${ }^{t} \mathrm{BuOMe}$ & 92 & 91 \\
\hline
\end{tabular}

${ }^{\mathrm{a}}$ The reaction was carried out on a $0.5 \mathrm{mmol}$ scale in $9 \mathrm{~mL}$ of solvent. ${ }^{\mathrm{b}}$ Enantiomer ratios were determined by HPLC analysis (Daicel Chiralcel OJ-H). $\quad{ }^{\circ}$ The reaction was carried out on a $0.5 \mathrm{mmol}$ scale in $18 \mathrm{~mL}$ of solvent. ${ }^{\mathrm{d}}$ The solid $\mathbf{2 a}$ (1.5 equiv.) was added over a period of $3 \mathrm{~h}$. $\quad{ }^{\mathrm{e}}$ The solid $\mathbf{2 a}$ (2.0 equiv.) was added over a period of $3 \mathrm{~h}$.

Next, a catalytic process of the hetero Diels-Alder reaction was investigated. That is, when 0.2 equivalent of $(R, R)$-DTBT was treated with 0.2 equivalent of propylzinc bromide, 1.0 equivalent of diisopropylzinc, 1.0 equivalent of $\mathbf{5}$, and 1.5 equivalents of solid $\mathbf{2 a}$ successively, the corresponding cycloadduct $6 \mathbf{a}$ was obtained with the enantioselectivity of $33 \%$ ee (Eq. 5). 


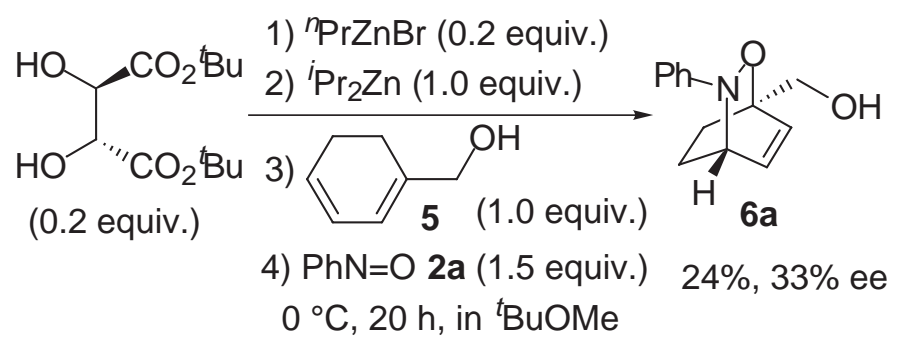

The conversion of all hydroxy groups in dienol $\mathbf{5}$ and DTBT into the corresponding bromozinc alkoxides by the treatment with propylzinc bromide, was found to be more effective to improve enantioselectivity of the corresponding cycloadduct $6 \mathbf{a}$ up to $66 \%$ ee (Eq. 6, Table 2, Entry 1). The cycloaddition in $\mathrm{CH}_{2} \mathrm{Cl}_{2}$ or toluene as a solvent furnished $6 \mathbf{a}$ with higher enantioselectivity of 79 and $78 \%$ ee, respectively (Entries 2 and 3). The reaction in ethylbenzene and cumene attained higher enantioselectivities over 80\% ee (Entries 4 and 5). However, the enantioselectivities were not reproducible. Several attempts using a 0.2 equivalent of $(R, R)$-DTBT, especially paying attention to anhydrous conditions, showed that the addition of MS 4A was crucial to realize extremely anhydrous conditions to obtain reproducible results. In the presence of MS 4A, the effect of the solvent was further examined (Entries 6-8, 10, 13 and 14). In aromatic solvents, the hetero Diels-Alder reaction proceeded smoothly to give 6a with over $70 \%$ ee. Enantioselectivities were varied depending on the kind of molecular sieves, and MS 4A was effective for higher entioselectivity (Entries 9-12). Finally, cumene was reproducibly realized the highest enantioselectivity of $83 \%$ ee though the difference was not so big among aromatic solvents.

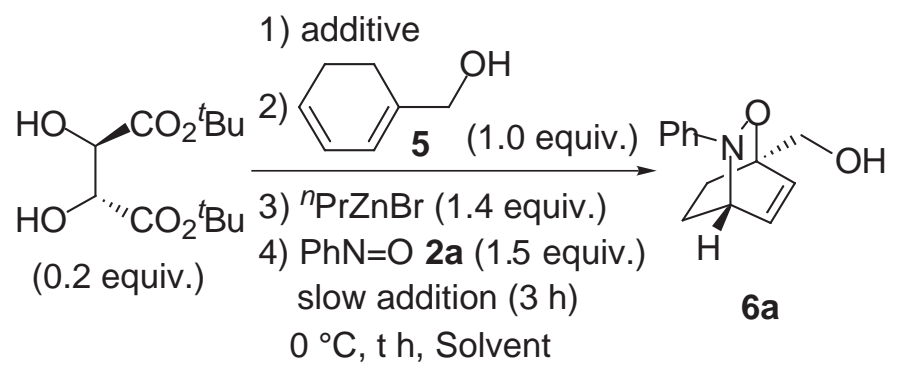

Next catalytic asymmetric hetero Diels-Alder reaction of several nitroso compounds $\mathbf{2}$ with the dienol $\mathbf{5}$ was performed (Eq. 7, Table 3). In the cases of nitrosobenzenes substituted with an electronwithdrawing group, such as nitro group, enantioselectivity was decreased, which suggested that such nitroso compounds were reactive enough without activation by chiral zinc moiety and non-catalyzed racemic reaction might have been accompanied (Entries 2-4). The nitrosobenzenes substituted with a methyl or phenoxy group showed good enantioselectivities (Entries 5 and 6). The hetero Diels-Alder reaction of the electron donating 4-(N,N-dimethylamino)-substituted nitrosobenzene $\mathbf{2 h}$ did not proceed at $0{ }^{\circ} \mathrm{C}$. Coordination of dimethylamino group to zinc metal might disturb the cycloaddition reaction. 
Table 2. The effect of solvent and additive (molecular sieves) ${ }^{\mathrm{a}}$

\begin{tabular}{|c|c|c|c|c|c|}
\hline Entry & Solvent & Additive & $\mathrm{t} / \mathrm{h}$ & Yield/\% & $\mathrm{ee} / \%^{\mathrm{b}}$ \\
\hline 1 & ${ }^{t} \mathrm{BuOMe}$ & -- & 20 & 83 & 66 \\
\hline 2 & $\mathrm{CH}_{2} \mathrm{Cl}_{2}$ & -- & 20 & 83 & 79 \\
\hline 3 & toluene & -- & 20 & 99 & 78 \\
\hline 4 & ethylbenzene & -- & 20 & 80 & 81 \\
\hline 5 & cumene & -- & 20 & 81 & 81 \\
\hline 6 & ${ }^{t} \mathrm{BuOMe}$ & MS 4A & 41 & 69 & 60 \\
\hline 7 & $\mathrm{Et}_{2} \mathrm{O}$ & MS 4A & 44 & 69 & 47 \\
\hline 8 & $\mathrm{CH}_{2} \mathrm{Cl}_{2}$ & MS 4A & 40 & 71 & 70 \\
\hline 9 & toluene & MS 3A & 20 & 70 & 67 \\
\hline 10 & & MS 4A & 20 & 77 & 74 \\
\hline 11 & & MS 5A & 20 & 72 & 66 \\
\hline 12 & & MS 13X & 20 & 78 & 44 \\
\hline 13 & ethylbenzene & MS 4A & 20 & 81 & 77 \\
\hline 14 & cumene & MS 4A & 20 & 86 & 83 \\
\hline
\end{tabular}

${ }^{a}$ The reaction was carried out on a $0.5 \mathrm{mmol}$ scale in $18 \mathrm{~mL}$ of solvent. ${ }^{b}$ Enantiomer ratios were determined by HPLC analysis (Daicel Chiralcel OJ-H).

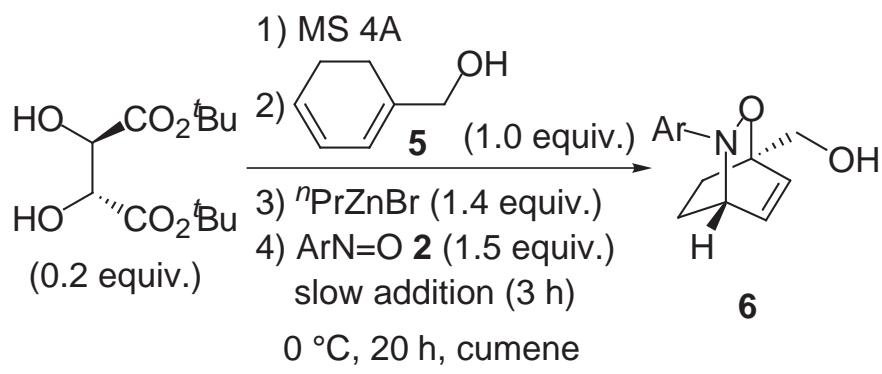

Table 3. Catalytic hetero Diels-Alder reaction of nitroso compounds $\mathbf{2}^{\mathrm{a}}$

\begin{tabular}{ccccc}
\hline Entry & $\mathrm{Ar}$ & & Yield $/ \%$ & $\mathrm{ee}^{\circ} \%^{\mathrm{b}}$ \\
\hline 1 & $\mathrm{Ph}$ & a & 86 & 83 \\
2 & ${ }^{p}\left(\mathrm{O}_{2} \mathrm{~N}\right) \mathrm{C}_{6} \mathrm{H}_{4}$ & b & 89 & 33 \\
3 & ${ }^{p}\left(\mathrm{MeO}_{2} \mathrm{C}\right) \mathrm{C}_{6} \mathrm{H}_{4}$ & c & 76 & 69 \\
4 & ${ }^{p} \mathrm{BrC}_{6} \mathrm{H}_{4}$ & d & 90 & 70 \\
5 & ${ }^{p} \mathrm{MeC}_{6} \mathrm{H}_{4}$ & e & 80 & 83 \\
6 & ${ }^{p}\left(\mathrm{PhO} \mathrm{C}_{6} \mathrm{H}_{4}\right.$ & f & $70^{c}$ & 76 \\
7 & ${ }^{p}\left(\mathrm{BuO}^{\mathrm{c}} \mathrm{C}_{6} \mathrm{H}_{4}\right.$ & g & 41 & 49 \\
8 & ${ }^{p}\left(\mathrm{Me}_{2} \mathrm{~N}\right) \mathrm{C}_{6} \mathrm{H}_{4}$ & h & -- & -- \\
\hline
\end{tabular}

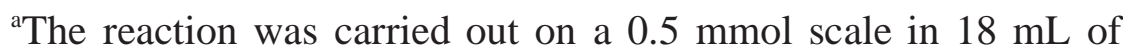
solvent. ${ }^{\mathrm{b}}$ Enantiomer ratios were determined by HPLC analysis (Daicel Chiralcel OJ-H). ${ }^{c}$ The regioisomer was obtained in $7 \%$ yield. 
Furthermore, catalytic asymmetric hetero Diels-Alder reaction to acyclic dienols $\mathbf{1 A}$ and $\mathbf{1 B}$ was carried out. However, the enantioselectivities were poor (Eq. 8).

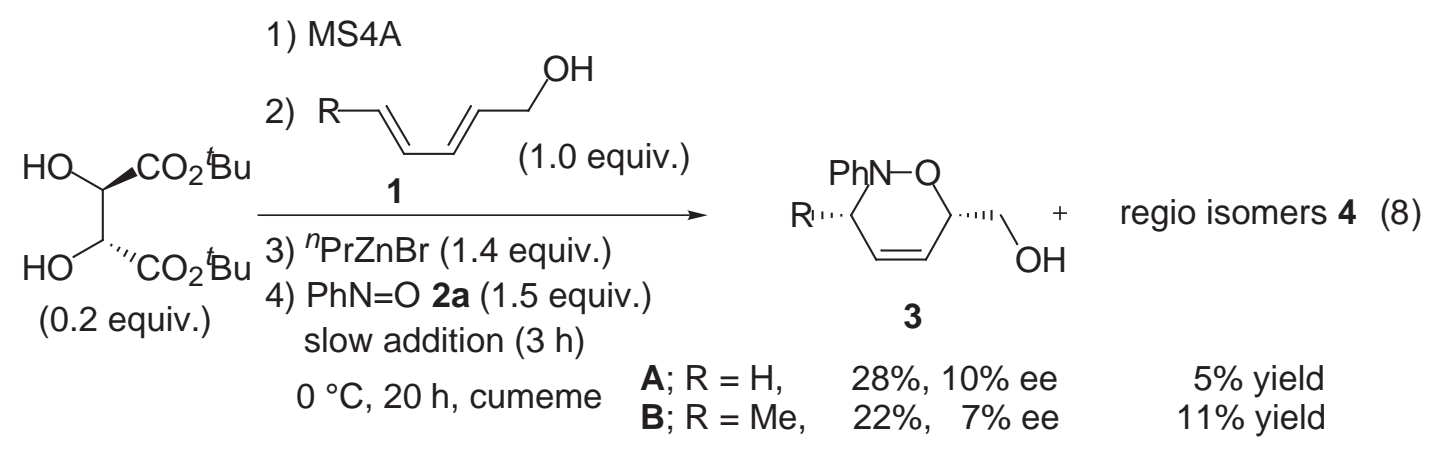

The absolute stereochemistry at the $\mathrm{C} 6$ position of $\mathbf{3 B}$ was confirmed to be $\mathrm{S}$ by chemical correlation: cycloadduct $3 \mathbf{B}\left(55 \%\right.$ ee) was transformed to compound $\mathbf{8}\left([\alpha]_{\mathrm{D}}^{25}+5\left(\mathrm{c} 0.12, \mathrm{CHCl}_{3}\right)\right)$ according to Scheme 1. The absolute configuration of $\mathbf{8}$ was determined to be $\mathrm{R}$ by the comparison with specific optical rotation of the known $(R)-\mathbf{8}\left(56 \%\right.$ ee; $\left.[\alpha]_{\mathrm{D}}+4.0\left(\mathrm{c} 1.0, \mathrm{CHCl}_{3}\right)\right) .{ }^{14}$ The stereochemistry of $\mathbf{3 A}$ was tentatively assigned to be $\mathrm{S}$.

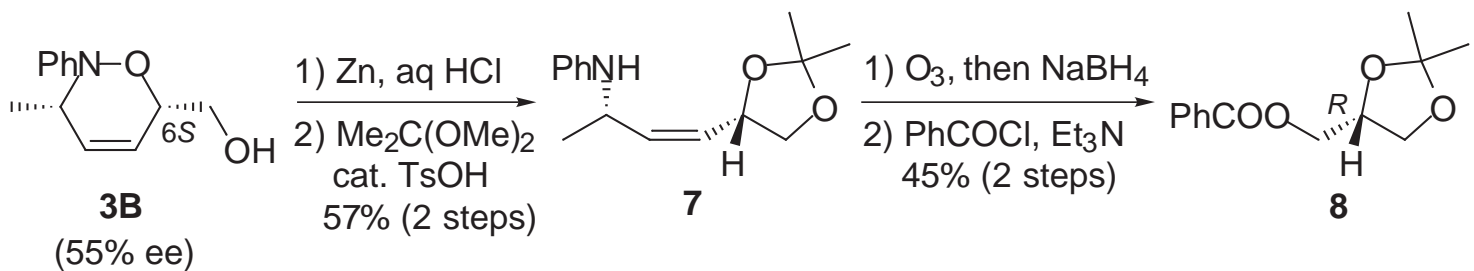

\section{Scheme 1}

Furthermore, the absolute configuration of $\mathbf{6 a}$ was determined to be $1 R, 4 S$ as follows: the enantiomerically rich 6a was treated with $(S)-N$-(4-nitrophenylsulfonyl)phenylalanyl chloride and triethylamine in the presence of a catalytic amount of DMAP in $\mathrm{CH}_{2} \mathrm{Cl}_{2}$ to give the corresponding ester 9 (71\%). The absolute stereochemistry of 9 was determined to be $1 R, 4 S$ by $\mathrm{X}$-ray crystallographic analysis of its single crystal, obtained by recrystallization from EtOAc, as shown in Figure 1. The stereochemistry of $\mathbf{6 b}-\mathbf{6} \mathbf{g}$ was tentatively assigned to be $1 R, 4 S$.

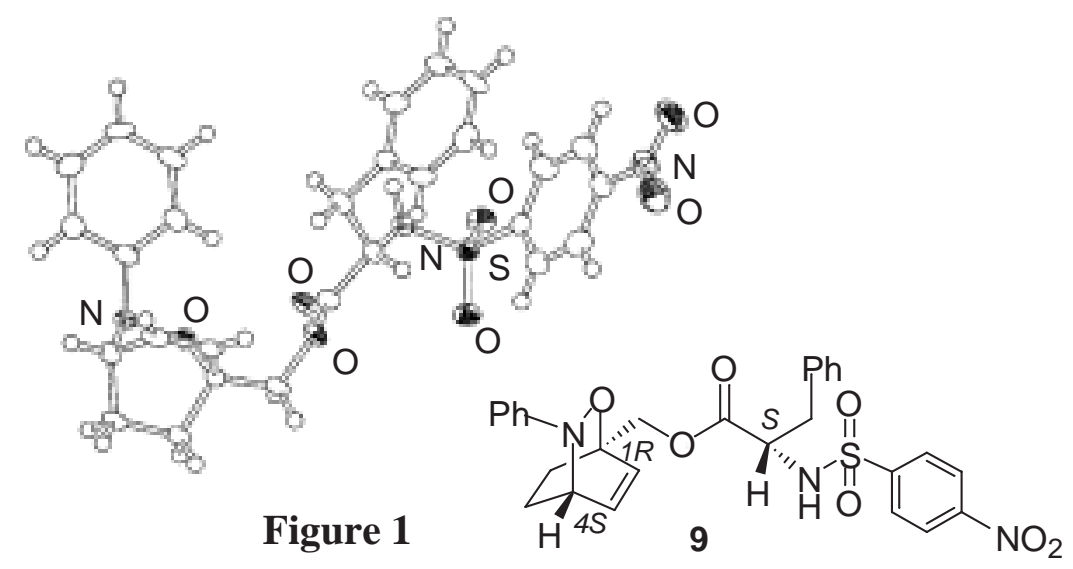


Although the precise reaction mechanism is not yet clear, the plausible transition state in the stoichiometric reaction of nitrosobenzene (2a) and dienol $\mathbf{1}$ is shown in Figure 2 to rationalize the absolute configuration of $\mathbf{3 B}$ determined above. Four kinds of transition state, endo-1, exo-1, endo-2, and exo-2, are possible. Among them, endo-1 and exo-1 might be disfavored due to steric hindrance between benzene ring of nitrosobenzene and the ester moiety of the tartrate. The cycloaddition might proceed via exo-2 leading to $(6 S)$-product in order to avoid steric congestion between benzene ring of nitrosobenzene and diene moiety in dienol $\mathbf{1}$ in preference to a secondary orbital interaction found in endo-2. When the cyclic dienol 5 was reacted with nitrosobenzene, both endo-3 and exo-3, are possible in which steric repulsion between the benzene ring of nitrosobenzene and cyclohexadiene moiety of dienol $\mathbf{5}$ is not so much different each other as shown in Figure 3. In this case, the secondary orbital interaction might prefer endo-3, leading to $1 R, 4 S$, to exo-3. In the catalytic reaction to $\mathbf{5}$, it is not yet clear whether the similar intermediate to that in the stoichiometric reaction was produced along with the generation of $\mathrm{ZnBr}_{2}$ or a different intermediate was formed. As a comparable level of chiral induction was realized in the reaction of $\mathbf{2 a}$ and $\mathbf{5}$, the essential part of the structure in the transition state might be common.

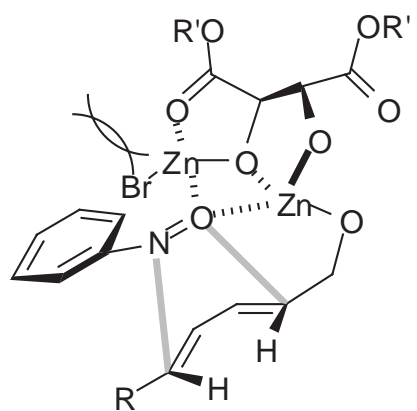

endo-1

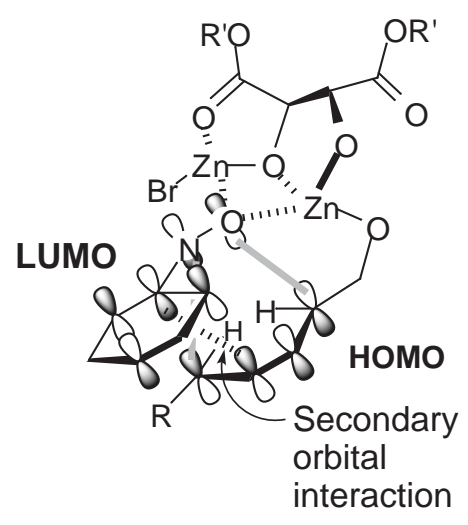

endo-2

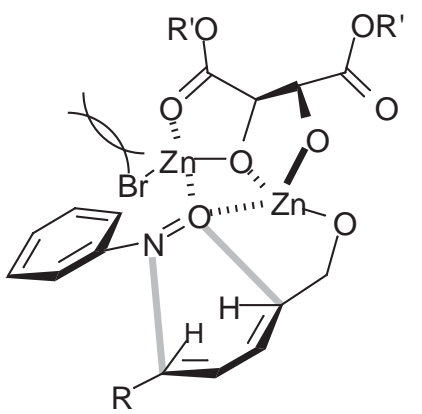

exo-1

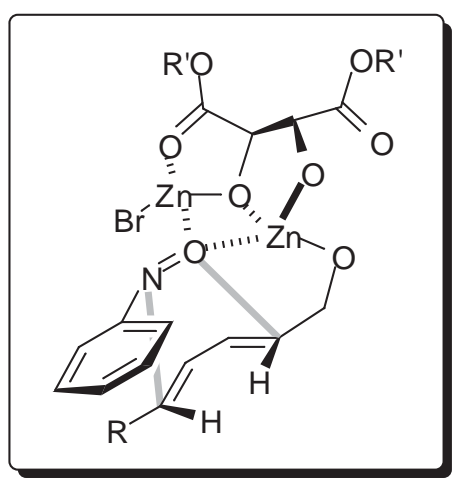

exo-2

Figure 2 


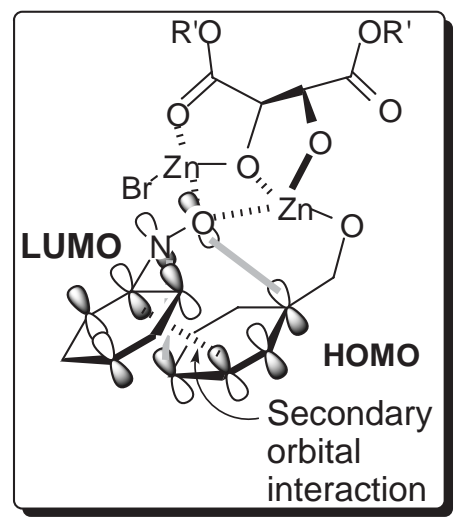

endo-3

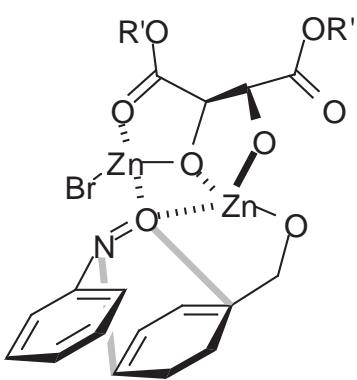

exo-3

Figure 3

In conclusion, we could establish an enantioselective hetero Diels-Alder reaction with nitroso compounds by utilizing tartaric acid ester as a chiral auxiliary. This approach will offer an appealing entry to the synthesis of six-membered heterocycles that are versatile synthetic intermediates for total syntheses of various natural products.

\section{EXPERIMENTAL}

${ }^{1} \mathrm{H}$ NMR spectra were recorded on a JEOL Lambda 400 NMR spectrometer. Chemical shifts were determined in the $\delta$-scale relative to TMS $(\delta=0 \mathrm{ppm})$ as an internal standard. IR spectra were measured on a JASCO FT/IR-230 spectrometer. MS spectra were recorded with a JEOL SX-102A mass spectrometers. THF and $\mathrm{Et}_{2} \mathrm{O}$ were freshly distilled from sodium diphenylketyl. $\mathrm{CHCl}_{3}$ was passed through aluminium oxide (Merck 1076) twice and further dried over MS 3A before use. All other solvents were distilled and dried over drying agents. Thin-layer chromatography (TLC) and flash column chromatography were performed by using Merck silica gel $60 \mathrm{PF}_{254}$ (Art. 7749) and Cica-Merck silica gel 60 (No. 9385-5B), respectively.

Stoichiometric asymmetric hetero Diels-Alder reaction of nitrosobenzene (2a) to $(E, E)-2,4-$ hexadien-1-ol (1B) (Eq. 2): To a solution of (E,E)-2,4-hexadien-1-ol (1B) $(49 \mathrm{mg}, 0.5 \mathrm{mmol})$ in $\mathrm{CHCl}_{3}$ $(3 \mathrm{~mL})$ was added diisopropylzinc $(1.0 \mathrm{M}$ solution in hexane, $0.5 \mathrm{~mL}, 0.5 \mathrm{mmol})$ at $0{ }^{\circ} \mathrm{C}$ under an argon atmosphere and stirred for $10 \mathrm{~min}$. A solution of $(R, R)$-DIPT $(117 \mathrm{mg}, 0.5 \mathrm{mmol})$ in $\mathrm{CHCl}_{3}(3 \mathrm{~mL})$ was further added dropwise and the resulting solution was kept for $10 \mathrm{~min}$ at the same temperature. Propylzinc bromide ( $0.5 \mathrm{M}$ solution in THF, $1 \mathrm{~mL}, 0.5 \mathrm{mmol})$ was added to the resulting solution. Stirring was continued for $1 \mathrm{~h}$, followed by addition of nitrosobenzene (2a) (54 mg, $0.5 \mathrm{mmol})$ in $\mathrm{CHCl}_{3}$ $(3 \mathrm{~mL})$. The resulting mixture was kept for $24 \mathrm{~h}$ at $0{ }^{\circ} \mathrm{C}$ and then treated with a saturated aq $\mathrm{NH}_{4} \mathrm{Cl}$ 
solution. After warming to $\mathrm{rt}$, the solvent was removed in vacuo and the residue was partitioned between EtOAc and water. The organic extracts were washed successively with water, brine and dried over $\mathrm{Na}_{2} \mathrm{SO}_{4}$. Evaporation of the solvent and separation of the residue by preparative TLC (hexane/EtOAc $=2 / 1, \mathrm{v} / \mathrm{v})$ afforded the products 3B (59 mg, 57\%) and 4B (29 mg, 28\%) as colorless oils. Enantiomer ratio of 3B was determined by HPLC analysis (Daicel Chiralcel OD-H, hexane/EtOH = 30/1, $\mathrm{v} / \mathrm{v}$ ).

In a similar manner, asymmetric hetero Diels-Alder reaction of nitrosobenzene (2a) to (E)-2,4-pentadien1-ol (1A) was carried out.

(S)-(2-Phenyl-3,6-dihydro-2H-1,2-oxazin-6-yl)methanol (3A): An oil. $\quad[\alpha]_{\mathrm{D}}^{25}+5$ (c 0.46 , EtOH; $33 \%$ ee). IR (neat) 3390, 3041, 2926, 2865, 2819, 1598, 1491, 1454, 1431, 1389, 1350, 1292, 1213, 1183, 1156, 1100, 1080, 1043, 1009, 876, 757, $691 \mathrm{~cm}^{-1} .{ }^{1} \mathrm{H}$ NMR $\left(\mathrm{CDCl}_{3}\right) \delta=2.57(1 \mathrm{H}$, brs $)$, 3.77-3.92 (4H, m), 4.62-4.64 (1H, m), $5.89(1 \mathrm{H}, \mathrm{dd}, J=10.25,1.71 \mathrm{~Hz}), 6.09(1 \mathrm{H}, \mathrm{m}), 7.03(1 \mathrm{H}, \mathrm{t}, J=$ $7.32 \mathrm{~Hz}), 7.16(2 \mathrm{H}, \mathrm{d}, J=8.29 \mathrm{~Hz}), 7.32(2 \mathrm{H}, \mathrm{dd}, J=8.29,7.32 \mathrm{~Hz}) . \quad \mathrm{HRMS}\left(\mathrm{EI}^{+}\right) \mathrm{M}^{+}$, Found: $m / z$ 191.09541. Calcd for $\mathrm{C}_{11} \mathrm{H}_{13} \mathrm{NO}_{2}: 191.09463$.

(2-Phenyl-3,6-dihydro-2H-1,2-oxazin-3-yl)methanol (4A): An oil. IR (neat) 3396, 3040, 2933, 2883, 2842, 1596, 1492, 1454, 1435, 1387, 1259, 1228, 1183, 1072, 1044, 1018, 975, 840, 758, $693 \mathrm{~cm}^{-1}$. ${ }^{1} \mathrm{H}$ NMR $\left(\mathrm{CDCl}_{3}\right) \delta=2.26(1 \mathrm{H}, \mathrm{dd}, J=7.56,4.88 \mathrm{~Hz}), 3.76(1 \mathrm{H}, \mathrm{ddd}, J=11.47,7.56,3.90 \mathrm{~Hz}), 3.84(1 \mathrm{H}$, ddd, $J=11.47,6.83,4.88 \mathrm{~Hz},), 4.14-4.19(1 \mathrm{H}, \mathrm{m}), 4.16(1 \mathrm{H}, \mathrm{dd}, J=15.86,1.95 \mathrm{~Hz}), 4.41(1 \mathrm{H}, \mathrm{dd}, J=$ $15.86,2.44 \mathrm{~Hz}), 5.97-5.98(2 \mathrm{H}, \mathrm{m}), 6.70(1 \mathrm{H}, \mathrm{t}, J=7.32 \mathrm{~Hz}), 7.11(2 \mathrm{H}, \mathrm{d}, J=8.78 \mathrm{~Hz}), 7.31(2 \mathrm{H}, \mathrm{dd}, J=$ 8.78, 7.32 Hz). HRMS (EI+ $\mathrm{M}^{+}$, Found: $m / z$ 191.09389. Calcd for $\mathrm{C}_{11} \mathrm{H}_{13} \mathrm{NO}_{2}: 191.09463$.

((3S,6S)-3-Methyl-2-phenyl-3,6-dihydro-2H-1,2-oxazin-6-yl)methanol (3B): An oil. $[\alpha]_{\mathrm{D}}^{25}+122(\mathrm{c}$ 0.63, EtOH; 55\% ee). IR (neat) 3371, 3038, 2974, 2929, 2869, 1598, 1492, 1453, 1390, 1362, 1340, $1258,1185,1133,1085,1047,953,896,853,757,736,694 \mathrm{~cm}^{-1} . \quad{ }^{1} \mathrm{H}$ NMR $\left(\mathrm{CDCl}_{3}\right) \delta=1.10(3 \mathrm{H}, \mathrm{d}, J=$ $6.59 \mathrm{~Hz}), 2.79(1 \mathrm{H}, \mathrm{br}), 3.79(1 \mathrm{H}, \mathrm{dd}, J=11.95,5.86 \mathrm{~Hz}), 3.89(1 \mathrm{H}, \mathrm{dd}, J=11.95,3.17 \mathrm{~Hz}), 4.08(1 \mathrm{H}$, qdd, $J=6.59,2.20,1.95 \mathrm{~Hz}), 4.60-4.62(1 \mathrm{H}, \mathrm{m}), 5.80(1 \mathrm{H}, \mathrm{ddd}, J=10.25,1.95,1.70 \mathrm{~Hz}), 6.05(1 \mathrm{H}, \mathrm{ddd}$, $J=10.25,3.90,2.20 \mathrm{~Hz}), 7.04(1 \mathrm{H}, \mathrm{t}, J=7.32 \mathrm{~Hz}), 7.14(2 \mathrm{H}, \mathrm{d}, J=7.81 \mathrm{~Hz}), 7.31(2 \mathrm{H}, \mathrm{dd}, J=7.81,7.32$ Hz). HRMS (EI') M+, Found: $m / z$ 205.10972. Calcd for $\mathrm{C}_{12} \mathrm{H}_{15} \mathrm{NO}_{2}: 205.11028$.

6-Methyl-2-phenyl-3,6-dihydro-2H-1,2-oxazin-3-yl)methanol (4B): An oil. IR (neat) 3397, 3038, 2975, 2930, 2871, 1597, 1492, 1453, 1388, 1372, 1329, 1258, 1184, 1146, 1126, 1086, 1034, 958, 929, 882, 842, 756, $693 \mathrm{~cm}^{-1} . \quad{ }^{1} \mathrm{H} \mathrm{NMR}\left(\mathrm{CDCl}_{3}\right) \delta=1.27(3 \mathrm{H}, \mathrm{d}, J=6.83 \mathrm{~Hz}), 2.34(1 \mathrm{H}, \mathrm{dd}, J=7.08,6.59$ Hz), $3.76(1 \mathrm{H}, \mathrm{ddd}, J=11.22,7.08,3.90 \mathrm{~Hz}), 3.82(1 \mathrm{H}, \mathrm{ddd}, J=11.22,6.59,4.39 \mathrm{~Hz}), 4.13-4.18(1 \mathrm{H}$, m), $4.48(1 \mathrm{H}, \mathrm{qdd}, J=6.83,4.39,1.22 \mathrm{~Hz}), 5.86(1 \mathrm{H}, \mathrm{dt}, J=10.25,1.22 \mathrm{~Hz}), 5.93(1 \mathrm{H}, \mathrm{ddd}, J=10.25$, 4.39, $1.22 \mathrm{~Hz}), 6.98(1 \mathrm{H}, \mathrm{t}, J=7.32 \mathrm{~Hz}), 7.07(2 \mathrm{H}, \mathrm{d}, J=8.78 \mathrm{~Hz}), 7.30(2 \mathrm{H}, \mathrm{dd}, J=8.78,7.32 \mathrm{~Hz})$. HRMS (EI+) $\mathrm{M}^{+}$, Found: $m / z$ 205.11113. Calcd for $\mathrm{C}_{12} \mathrm{H}_{15} \mathrm{NO}_{2}: 205.11028$. 
Stoichiometric asymmetric hetero Diels-Alder reaction of nitrosobenzene (2a) to cyclohexa-1,3dienylmethanol (5) (Table 1, Entry 17): To a solution of $(R, R)$-DTBT (131 $\mathrm{mg}, 0.5 \mathrm{mmol})$ in $t$-butyl methyl ether $(9 \mathrm{~mL})$ was added propylzinc bromide $(0.5 \mathrm{M}$ solution in THF, $1 \mathrm{~mL}, 0.5 \mathrm{mmol})$ at $0{ }^{\circ} \mathrm{C}$ under an argon atmosphere and the resulting solution was kept for $15 \mathrm{~min}$ with stirring. Diisopropylzinc (1.0 M solution in hexane, $0.5 \mathrm{~mL}, 0.5 \mathrm{mmol}$ ) was further added at the same temperature. After stirring for another $15 \mathrm{~min}$, a solution of cyclohexa-1,3-dienylmethanol (5) (55 mg, $0.5 \mathrm{mmol})$ in $t$-butyl methyl ether $(9 \mathrm{~mL})$ was added. Stirring was continued for $1 \mathrm{~h}$, followed by addition of solid nitrosobenzene (2a) $(81 \mathrm{mg}, 0.75 \mathrm{mmol})$ over a period of $3 \mathrm{~h}$. The resulting mixture was kept for $20 \mathrm{~h}$ at $0{ }^{\circ} \mathrm{C}$ and then treated with a saturated aq $\mathrm{NH}_{4} \mathrm{Cl}$ solution. After warming to rt, the solvent was removed in vacuo and the residue was partitioned between EtOAc and water. The organic extracts were washed successively with water, brine and dried over $\mathrm{Na}_{2} \mathrm{SO}_{4}$. Evaporation of the solvent and separation of the residue by preparative TLC (hexane/EtOAc $=2 / 1, \mathrm{v} / \mathrm{v})$ afforded the desired cycloadduct $6 \mathbf{a}$ as a colorless oil (101 mg, 94\%). Enantiomer ratio was determined to be $92 \%$ ee by HPLC analysis (Daicel Chiralcel OJ-H, hexane/EtOH = 2/1, v/v).

$(\mathbf{1 R}, 4 S)-\left(3-P h e n y l-2-o x a-3-a z a-b i c y c l o[2.2 .2]\right.$ oct-5-en-1-yl)methanol (6a): An oil. $[\alpha]_{\mathrm{D}}^{25}-60$ (c 1.69, EtOH; 92\% ee). IR (neat) 3389, 3057, 2934, 2860, 1596, 1488, 1451, 1377, 1224, 1190, 1101, 1058, 972, 907, 872, 849, 806, 763, $698 \mathrm{~cm}^{-1} .{ }^{1} \mathrm{H}$ NMR $\left(\mathrm{CDCl}_{3}\right) \delta=1.28(1 \mathrm{H}, \mathrm{ddd}, J=12.20,11.95$, $4.15 \mathrm{~Hz}), 1.62(1 \mathrm{H}, \mathrm{ddt}, J=12,69,11.95,3.17 \mathrm{~Hz}), 1.89$ (1H, brs), 2.06 (1H, ddd, $J=12.20,9.51,3.17$ Hz), $2.34(1 \mathrm{H}, \mathrm{dddd}, J=12.69,9.51,4.15,2.92 \mathrm{~Hz}), 3.86(1 \mathrm{H}, \mathrm{d}, J=12.20 \mathrm{~Hz}), 3.90(1 \mathrm{H}, \mathrm{d}, J=12.20$ $\mathrm{Hz}), 4.42(1 \mathrm{H}, \mathrm{dddd}, J=5.60,3.17,2.92,1.44 \mathrm{~Hz}), 6.17(1 \mathrm{H}, \mathrm{dd}, J=8.27,5.60 \mathrm{~Hz}), 6.53(1 \mathrm{H}, \mathrm{dd}, J=$ $8.271 .44 \mathrm{~Hz}), 6.93(1 \mathrm{H}, \mathrm{t}, J=7.32 \mathrm{~Hz}), 6.99(2 \mathrm{H}, \mathrm{d}, J=7.81 \mathrm{~Hz}), 7.21(2 \mathrm{H}, \mathrm{dd}, J=7.81,7.32 \mathrm{~Hz})$. HRMS $\left(\mathrm{FAB}^{+}\right)(\mathrm{M}+\mathrm{H})^{+}$, Found: $m / z$ 218.11831. Calcd for $\mathrm{C}_{13} \mathrm{H}_{16} \mathrm{NO}_{2}: 218.11810$.

Representative Procedure for catalytic asymmetric hetero Diels-Alder reaction of nitrosobenzene (2a) to cyclohexa-1,3-dienylmethanol (5) (Table 3, Entry 1): MS 4A (300 mg) was activated by heating prior to use under reduced pressure. To a mixed solution of $(R, R)$-DTBT (26 mg, $0.1 \mathrm{mmol})$ and cyclohexa-1,3-dienylmethanol (5) $(55 \mathrm{mg}, 0.5 \mathrm{mmol})$ in cumene $(18 \mathrm{~mL})$ in the presence of MS 4A was added propylzinc bromide $(0.5 \mathrm{M}$ solution in THF, $1.4 \mathrm{~mL}, 0.7 \mathrm{mmol})$ at $0{ }^{\circ} \mathrm{C}$ under an argon atmosphere. After stirring for $10 \mathrm{~min}$, solid nitrosobenzene (2a) $(81 \mathrm{mg}, 0.75 \mathrm{mmol})$ was added over a period of $3 \mathrm{~h}$. The resulting mixture was kept for $20 \mathrm{~h}$ at $0{ }^{\circ} \mathrm{C}$ and then treated with a saturated aq $\mathrm{NH}_{4} \mathrm{Cl}$ solution, and the solvent was evaporated. The organic substances were extracted with EtOAc, followed by washing with $\mathrm{H}_{2} \mathrm{O}$, brine, and dried over $\mathrm{Na}_{2} \mathrm{SO}_{4}$. After evaporating the solvent, the residue was purified by a column chromatography $\left(\mathrm{SiO}_{2}\right.$, hexane/EtOAc $\left.=2 / 1, \mathrm{v} / \mathrm{v}\right)$ to give the corresponding hetero Diels-Alder adduct $6 \mathbf{a}$ as a colorless oil $(93 \mathrm{mg}, 86 \%)$. Enantiomer ratio was determined to be $83 \%$ ee by HPLC analysis (Daicel Chiralcel OJ-H, hexane/EtOH = 2/1, v/v). 
In a similar manner, catalytic asymmetric hetero Diels-Alder reaction of nitroso compounds $\mathbf{2 b}-\mathbf{2 h}$ was performed.

((1R,4S)-3-(4-Nitrophenyl)-2-oxa-3-azabicyclo[2.2.2]oct-5-en-1-yl)methanol (6b): A solid. Mp 126-127 ${ }^{\circ} \mathrm{C}$ (from EtOH). $\quad[\alpha]_{\mathrm{D}}^{25}-3$ (c 1.17, EtOH; 33\% ee). IR (KBr) 3569, 3385, 3105, 2928, 1589, $1504,1491,1335,1263,1182,1116,1051,979,968,845,751,718 \mathrm{~cm}^{-1} .{ }^{1} \mathrm{H}$ NMR $\left(\mathrm{CDCl}_{3}\right) \delta=1.32$ $(1 \mathrm{H}, \mathrm{ddd}, J=12.69,11.95,4.15 \mathrm{~Hz}), 1.70(1 \mathrm{H}, \mathrm{ddt}, J=13.17,11.95,3.17 \mathrm{~Hz}), 1.86(1 \mathrm{H}, \mathrm{t}, J=6.83 \mathrm{~Hz})$, $2.11(1 \mathrm{H}, \mathrm{ddd}, J=12.68,9.51,3.17 \mathrm{~Hz}), 2.34(1 \mathrm{H}, \mathrm{dddd}, J=13.17,9.51,4.15,3.17 \mathrm{~Hz}), 3.92(1 \mathrm{H}, \mathrm{dd}, J$ $=12.20,6.83 \mathrm{~Hz}), 3.96(1 \mathrm{H}, \mathrm{dd}, J=12.20,6.83 \mathrm{~Hz}), 4.67(1 \mathrm{H}, \mathrm{dtd}, J=5.61,3.17,1.46 \mathrm{~Hz}), 6.31(1 \mathrm{H}, \mathrm{dd}$, $J=8.29,5.61 \mathrm{~Hz}), 6.54(1 \mathrm{H}, \mathrm{dd}, J=8.29,1.46 \mathrm{~Hz}), 7.03(2 \mathrm{H}, \mathrm{d}, J=9.27 \mathrm{~Hz}), 8.11(2 \mathrm{H}, \mathrm{d}, J=9.27 \mathrm{~Hz})$. Found: C, 59.60; H, 5.49; N, 10.67\%. Calcd for $\mathrm{C}_{13} \mathrm{H}_{14} \mathrm{~N}_{2} \mathrm{O}_{4}: \mathrm{C}, 59.53 ; \mathrm{H}, 5.38 ; \mathrm{N}, 10.68 \%$.

Methyl 4-((1R,4S)-1-(Hydroxymethyl)-2-oxa-3-azabicyclo[2.2.2]oct-5-en-3-yl)benzoate (6c): A solid. Mp $129-130{ }^{\circ} \mathrm{C}$ (from EtOAc/hexane). [ $\left.\alpha\right]_{\mathrm{D}}{ }^{25}-38$ (c 0.84, EtOH; 69\% ee). IR (KBr) 3476, 2966, 2936, 2909, 2858, 1685, 1600, 1504, 1433, 1315, 1283, 1255, 1238, 1227, 1184, 1172, 1114, 1097. 1059, 1007, 981, 855, 776, $715 \mathrm{~cm}^{-1} . \quad{ }^{1} \mathrm{H} \mathrm{NMR}\left(\mathrm{CDCl}_{3}\right) \delta=1.32(1 \mathrm{H}, \mathrm{ddd}, J=12.44,11.95,4.15 \mathrm{~Hz})$, $1.67(1 \mathrm{H}, \mathrm{dddd}, J=12.93,11.95,3.17,2.93 \mathrm{~Hz}), 1.90(1 \mathrm{H}, \mathrm{t}, J=7.07 \mathrm{~Hz}), 2.09(1 \mathrm{H}, \mathrm{ddd}, J=12.44,9.51$, $3.17 \mathrm{~Hz}), 2.34(1 \mathrm{H}, \mathrm{dddd}, J=12.93,9.51,4.15,2.93 \mathrm{~Hz}), 3.89(3 \mathrm{H}, \mathrm{s}), 3.89(1 \mathrm{H}, \mathrm{dd}, J=12.20,7.07 \mathrm{~Hz})$, $3.94(1 \mathrm{H}, \mathrm{dd}, J=12.20,7.07 \mathrm{~Hz}), 4.58-4.61(1 \mathrm{H}, \mathrm{m}), 6.25(1 \mathrm{H}, \mathrm{dd}, J=8.295 .61 \mathrm{~Hz}), 6.51(1 \mathrm{H}, \mathrm{dd}, J=$ 8.29, $1.22 \mathrm{~Hz}), 7.00(2 \mathrm{H}, \mathrm{d}, J=8.54 \mathrm{~Hz}), 7.90(2 \mathrm{H}, \mathrm{d}, J=8.54 \mathrm{~Hz})$. Found: C, 65.28; H, 6.30; N, 5.02\%. Calcd for $\mathrm{C}_{15} \mathrm{H}_{17} \mathrm{NO}_{4}$ : C, 65.44; H, 6.22; N, 5.09\%.

$\left((1 R, 4 S)-3-(4-B r o m o p h e n y l)-2-o x a-3-a z a b i c y c l o[2.2 .2]\right.$ oct-5-en-1-yl)methanol $(6 \mathrm{~d}): \quad$ An oil. $[\alpha]_{\mathrm{D}}^{25}$ +70 (c 0.63, EtOH; 70\% ee). IR (neat) 3390, 3056, 2935, 2861, 1584, 1483, 1455, 1398, 1376, 1225, 1191, 1058, 1003, 972, 827, $714 \mathrm{~cm}^{-1} . \quad{ }^{1} \mathrm{H} \mathrm{NMR}\left(\mathrm{CDCl}_{3}\right) \delta=1.29(1 \mathrm{H}, \mathrm{ddd}, J=12.44,11.95,4.15 \mathrm{~Hz})$, $1.64(1 \mathrm{H}, \mathrm{ddt}, J=12.93,11.71,3.17 \mathrm{~Hz}), 1.93(1 \mathrm{H}, \mathrm{brs}), 2.06(1 \mathrm{H}$, ddd $J=12.44,9.51,3.17 \mathrm{~Hz}), 2.33$ $(1 \mathrm{H}, \mathrm{dddd}, J=12.93,9.51,4.15,2.92 \mathrm{~Hz}), 3.87(1 \mathrm{H}, \mathrm{d}, J=12.20 \mathrm{~Hz}), 3.92(1 \mathrm{H}, \mathrm{d}, J=12.20 \mathrm{~Hz}), 4.39$ $(1 \mathrm{H}, \mathrm{dddd}, J=5.61,3.17,2.92,1.46 \mathrm{~Hz}), 6.18(1 \mathrm{H}, \mathrm{dd}, J=8.29,5.61 \mathrm{~Hz}), 6.53(1 \mathrm{H}, \mathrm{dd}, J=8.29,1.46$ $\mathrm{Hz}), 6.87(2 \mathrm{H}, \mathrm{d}, J=8.78 \mathrm{~Hz}), 7.31(2 \mathrm{H}, \mathrm{d}, J=8.78 \mathrm{~Hz}) . \quad \operatorname{HRMS}\left(\mathrm{FAB}^{+}\right)(\mathrm{M}+\mathrm{H})^{+}$, Found: $m / z$ 269.02847. Calcd for $\mathrm{C}_{13} \mathrm{H}_{15} \mathrm{NO}_{2} \mathrm{Br}: 296.02861$.

$\left((1 R, 4 S)-3-(4-T o l y l)-2-o x a-3-a z a b i c y c l o[2.2 .2]\right.$ oct-5-en-1-yl)methanol (6e): An oil. $[\alpha]_{\mathrm{D}}^{25}-56$ (c 0.93, EtOH; 83\% ee). IR (neat) 3390, 3024, 2933, 2861, 1610, 1505, 1453, 1377, 1223, 1190, 1100, 1059, 1014, 973, 849, 822, 750, $704 \mathrm{~cm}^{-1} . \quad{ }^{1} \mathrm{H} \operatorname{NMR}\left(\mathrm{CDCl}_{3}\right) \delta=1.27(1 \mathrm{H}, \mathrm{td}, J=12.20,4.16 \mathrm{~Hz}), 1.61$ (1H, dddd, $J=12.68,12.20,3.42,2.93 \mathrm{~Hz}), 1.85$ (1H, brs), 2.05 (1H, ddd $J=12.20,9.86,3.42 \mathrm{~Hz}), 2.26$ $(3 \mathrm{H}, \mathrm{s}), 2.30-2.37(1 \mathrm{H}, \mathrm{m}), 3.85(1 \mathrm{H}, \mathrm{d}, J=12.20 \mathrm{~Hz}), 3.90(1 \mathrm{H}, \mathrm{d}, J=12.20 \mathrm{~Hz}), 4.36(1 \mathrm{H}, \mathrm{ddd}, J=$ 5.85, 2.93, $2.68 \mathrm{~Hz}), 6.18(1 \mathrm{H}, \mathrm{dd}, J=8.29,5.85 \mathrm{~Hz}), 6.53(1 \mathrm{H}, \mathrm{d}, J=8.29 \mathrm{~Hz}), 6.88(2 \mathrm{H}, \mathrm{d}, J=8.05 \mathrm{~Hz})$, $7.01(2 \mathrm{H}, \mathrm{d}, J=8.05 \mathrm{~Hz})$. HRMS $\left(\mathrm{FAB}^{+}\right)(\mathrm{M}+\mathrm{H})^{+}$, Found: $m / z$ 232.13350. Calcd for $\mathrm{C}_{14} \mathrm{H}_{18} \mathrm{NO}_{2}$ : 
232.13375.

((1R,4S)-3-(4-Phenoxyphenyl)-2-oxa-3-azabicyclo[2.2.2] oct-5-en-1-yl)methanol (6f): An oil. $[\alpha]_{\mathrm{D}}^{25}-69$ (c 1.04, EtOH; 76\% ee). IR (neat) 3390, 3058, 2934, 2861, 1589, 1489, 1455, 1376, 1239, 1102, 1058, 974, 871, 847, 759, $693 \mathrm{~cm}^{-1} . \quad{ }^{1} \mathrm{H}$ NMR $\left(\mathrm{CDCl}_{3}\right) \delta=1.28(1 \mathrm{H}, \mathrm{ddd}, J=12.46,11.95,4.15$ Hz), $1.62(1 \mathrm{H}, \mathrm{dddd}, J=12.93,11.95,3.42,2.92 \mathrm{~Hz}), 2.05(1 \mathrm{H}, \operatorname{ddd} J=12.46,9.51,3.42 \mathrm{~Hz}), 2.23(1 \mathrm{H}$, brs), 2.34 (1H, dddd, $J=12.93,9.51,4.15,2.92 \mathrm{~Hz}), 3.85(1 \mathrm{H}, \mathrm{d}, J=12.20 \mathrm{~Hz}), 3.90(1 \mathrm{H}, \mathrm{d}, J=12.20$ $\mathrm{Hz}), 4.33(1 \mathrm{H}, \mathrm{dtd}, J=5.86,2.92,1.46 \mathrm{~Hz}), 6.19(1 \mathrm{H}, \mathrm{dd}, J=8.54,5.86 \mathrm{~Hz}), 6.56(2 \mathrm{H}, \mathrm{dd}, J=8.54,1.46$ $\mathrm{Hz}), 6.88(2 \mathrm{H}, \mathrm{d}, J=9.03 \mathrm{~Hz}), 6.94(2 \mathrm{H}, \mathrm{d}, J=8.78 \mathrm{~Hz}), 6.97(2 \mathrm{H}, \mathrm{d}, J=9.03 \mathrm{~Hz}), 7.04(1 \mathrm{H}, \mathrm{t}, J=7.32$ $\mathrm{Hz}), 7.29(2 \mathrm{H}, \mathrm{dd}, J=8.78,7.32 \mathrm{~Hz})$. HRMS $\left(\mathrm{FAB}^{+}\right)(\mathrm{M}+\mathrm{H})^{+}$, Found: $m / z$ 310.14438. Calcd for $\mathrm{C}_{19} \mathrm{H}_{20} \mathrm{NO}_{3}: 310.14432$.

(3-(4-Phenoxyphenyl)-2-oxa-3-azabicyclo[2.2.2]oct-5-en-4-yl)methanol (Regioisomer of 6f): An oil. IR (neat) 3358, 3027, 2925, 2852, 1610, 1588, 1507, 1488, 1313, 1229, 1163, 1100, 1049, 900, 872, 830, $751,691 \mathrm{~cm}^{-1} . \quad{ }^{1} \mathrm{H}$ NMR $\left(\mathrm{CDCl}_{3}\right) \delta=1.26(1 \mathrm{H}, \mathrm{t}, J=7.56 \mathrm{~Hz}), 1.66-1.76(1 \mathrm{H}, \mathrm{m}), 1.85(1 \mathrm{H}, \mathrm{dd} J=$ 10.73, $7.56 \mathrm{~Hz}), 2.02-2.07(1 \mathrm{H}, \mathrm{m}), 2.17(1 \mathrm{H}, \mathrm{brs}), 3.51(1 \mathrm{H}, \mathrm{d}, J=10.73 \mathrm{~Hz}), 3.55(1 \mathrm{H}, \mathrm{d}, J=10.73 \mathrm{~Hz})$, 3.89-3.94 (1H, m), $5.81(1 \mathrm{H}, \mathrm{d}, J=10.00 \mathrm{~Hz}), 5.98(1 \mathrm{H}, \mathrm{dd}, J=10.00,2.20 \mathrm{~Hz}), 6.62(2 \mathrm{H}, \mathrm{d}, J=8.78$ $\mathrm{Hz}), 6.90(2 \mathrm{H}, \mathrm{d}, J=8.78 \mathrm{~Hz}), 6.93(2 \mathrm{H}, \mathrm{d}, J=8.54 \mathrm{~Hz}), 7.01(1 \mathrm{H}, \mathrm{t}, J=7.32 \mathrm{~Hz}), 7.27(2 \mathrm{H}, \mathrm{dd}, J=8.54$, $7.32 \mathrm{~Hz})$. HRMS $\left(\mathrm{FAB}^{+}\right)(\mathrm{M}+\mathrm{H})^{+}$, Found: $m / z$ 310.14387. Calcd for $\mathrm{C}_{19} \mathrm{H}_{20} \mathrm{NO}_{3}: 310.14432$.

$\left((1 R, 4 S)-3-(4-B u t o x y p h e n y l)-2-o x a-3-a z a b i c y c l o[2.2 .2]\right.$ oct-5-en-1-yl)methanol (6g): An oil. $[\alpha]_{\mathrm{D}}^{25}$ -831 (c 0.232, EtOH; 54\% ee). IR (neat) 3348, 2932, 2867, 1615, 1514, 1473, 1393, 1295, 1231, 1032 , 972, 901, $819 \mathrm{~cm}^{-1} . \quad{ }^{1} \mathrm{H} \mathrm{NMR}\left(\mathrm{CDCl}_{3}\right) \delta=0.96(3 \mathrm{H}, \mathrm{t}, J=7.32 \mathrm{~Hz}), 1.47(2 \mathrm{H}$, sext, $J=7.32 \mathrm{~Hz})$, 1.65-2.05 (5H, m), 1.79-1.86 (1H, m), 1.99-2.04 (1H, m), $3.50(1 \mathrm{H}, \mathrm{d}, J=10.98 \mathrm{~Hz}), 3.54(1 \mathrm{H}, \mathrm{d}, J=$ $10.98 \mathrm{~Hz}), 3.83-3.90(1 \mathrm{H}, \mathrm{m}), 3.89(2 \mathrm{H}, \mathrm{t}, J=6.58 \mathrm{~Hz}), 5.78(1 \mathrm{H}, \mathrm{d}, J=10.25 \mathrm{~Hz}), 5.97(1 \mathrm{H}, \mathrm{dd}, J=$

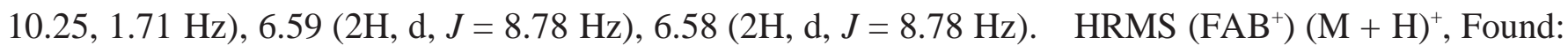
$m / z$ 290.17539. Calcd for $\mathrm{C}_{17} \mathrm{H}_{24} \mathrm{NO}_{3}: 290.17562$.

Transformation of $3 B$ to $8 . \quad N-[(S, Z)-4-[(S)-2,2-D i m e t h y l-1,3-d i o x o l a n-4-y l]-3-b u t e n-2-y l]$ aniline (7): To a $\mathrm{MeOH}$ (3 mL) solution of 3B (58 mg, $0.28 \mathrm{mmol}, 55 \%$ ee) was added zinc powder (97 $\mathrm{mg}, 1.48$ $\mathrm{mmol})$ and $3 \mathrm{M}$ aq $\mathrm{HCl}(1.0 \mathrm{~mL}, 3.0 \mathrm{mmol})$ and the suspension was stirred vigorously at rt overnight. ${ }^{8 \mathrm{a}}$ The reaction mixture was quenched by adding of a saturated aq $\mathrm{NaHCO}_{3}$ solution $(2 \mathrm{~mL})$. After filtration of the insoluble substance, the filtrate was extracted with $\mathrm{CHCl}_{3}$. The combined organic extracts were dried over $\mathrm{Na}_{2} \mathrm{SO}_{4}$ and concentrated under reduced pressure. To a mixed solution of the condensed residue and a catalytic amount of TsOH$\cdot \mathrm{H}_{2} \mathrm{O}$ in DMF (4 mL) were added acetone $(1.3 \mathrm{~mL})$ and $\mathrm{Me}_{2} \mathrm{C}(\mathrm{OMe})_{2}(0.26 \mathrm{~mL}, 1.9 \mathrm{mmol})$ under a nitrogen atmosphere, and the mixture was stirred at $0{ }^{\circ} \mathrm{C}$ overnight. The reaction was quenched by the addition of a saturated aq $\mathrm{NaHCO}_{3}$ solution $(1 \mathrm{~mL})$, and the solution was extracted by $\mathrm{Et}_{2} \mathrm{O}$. The combined organic extracts were washed successively with 
water and brine, and then dried over $\mathrm{Na}_{2} \mathrm{SO}_{4}$. Evaporation of the solvent and separation of the residue by preparative TLC (hexane/EtOAc $=6 / 1, \mathrm{v} / \mathrm{v}$ ) afforded $7(40 \mathrm{mg})$ in $57 \%$ yield in 2 steps. An oil. $[\alpha]_{\mathrm{D}}^{25}+61(\mathrm{c} 0.40, \mathrm{EtOH}) . \quad$ IR (neat) 3384, 3052, 2984, 2930, 2871, 1603, 1505, 1371, 1317, 1254, 1214, 1155, 1060, 860, 749, $693 \mathrm{~cm}^{-1} .{ }^{1} \mathrm{H} \mathrm{NMR}\left(\mathrm{CDCl}_{3}\right) \delta=1.28(3 \mathrm{H}, \mathrm{d}, J=6.83 \mathrm{~Hz}), 1.42(3 \mathrm{H}, \mathrm{s}), 1.45(3 \mathrm{H}$, s), $3.55(1 \mathrm{H}, \mathrm{dd}, J=8.05,7.81 \mathrm{~Hz}), 3.65(1 \mathrm{H}, \mathrm{brs}), 4.06(1 \mathrm{H}, \mathrm{dd}, J=8.05,6.10 \mathrm{~Hz}), 4.27(1 \mathrm{H}, \mathrm{dq}, J=$ 7.56, $6.83 \mathrm{~Hz}), 4.98(1 \mathrm{H}, \mathrm{td}, J=7.81,6.10 \mathrm{~Hz}), 5.50(1 \mathrm{H}, \mathrm{dd}, J=11.22,7.56 \mathrm{~Hz}), 5.55(1 \mathrm{H}, \mathrm{dd}, J=11.22$, $7.81 \mathrm{~Hz}), 6.62(2 \mathrm{H}, \mathrm{d}, J=8.54 \mathrm{~Hz}), 6.70(1 \mathrm{H}, \mathrm{t}, J=7.32 \mathrm{~Hz}), 7.16(2 \mathrm{H}, \mathrm{dd}, J=8.54,7.32 \mathrm{~Hz}) . \quad \mathrm{HRMS}$ $\left(\mathrm{EI}^{+}\right) \mathrm{M}^{+}$, Found: $m / z$ 247.15700. Calcd for $\mathrm{C}_{15} \mathrm{H}_{21} \mathrm{NO}_{2}: 247.15723$.

(R)-(2,2-Dimethyl-1,3-dioxolan-4-yl)methyl Benzoate (8): Under an oxygen atmosphere, ozone containing oxygen was bubbled into a $\mathrm{CH}_{2} \mathrm{Cl}_{2}(10 \mathrm{~mL})$ solution of $7(28 \mathrm{mg}, 0.11 \mathrm{mmol})$ for $1 \mathrm{~h}$ at $-78{ }^{\circ} \mathrm{C}$. After the color of the solution changed to blue, ozone free oxygen was further bubbled until the color of the solution became colorless again, and $\mathrm{NaBH}_{4}(66 \mathrm{mg}, 1.74 \mathrm{mmol})$ and $\mathrm{EtOH}(10 \mathrm{~mL})$ was added. After warming to rt, the resulting solution was allowed to be stirred at $50{ }^{\circ} \mathrm{C}$ for $1 \mathrm{~h}$ and at rt overnight. ${ }^{15}$ The reaction was quenched by the addition of water $(10 \mathrm{~mL})$, and extracted by $\mathrm{CHCl}_{3}$. The organic extracts were dried over $\mathrm{Na}_{2} \mathrm{SO}_{4}$ and concentrated under reduced pressure to give a residue containing (2,2-dimethyl-1,3-dioxolan-4-yl)methanol. A mixture of the residue, triethylamine (29 $\mathrm{mg}, 0.29 \mathrm{mmol}$ ), benzoyl chloride (33 mg, $0.24 \mathrm{mmol}$ ), and a catalytic amount of DMAP in $\mathrm{CH}_{2} \mathrm{Cl}_{2}(1 \mathrm{~mL})$ was stirred for $3 \mathrm{~h}$ under a nitrogen atmosphere at rt. To the solution was added water, and the resulting solution was extracted with EtOAc. The combined extracts were dried over $\mathrm{Na}_{2} \mathrm{SO}_{4}$ and concentrated under reduced pressure. Purification by TLC on silica gel (hexane/EtOAc $=7 / 1$, v/v) gave $(R)$-(2,2-dimethyl-1,3dioxolan-4-yl)methyl benzoate (8) (12 mg) in 45\% yield in 2 steps. Enantiomer ratio of the obtained 8 was confirmed to be 55\% ee by HPLC analysis (Daicel Chiralcel OD-H, hexane/ $\mathrm{PrOH}=100 / 1$, v/v). An oil. $[\alpha]_{\mathrm{D}}{ }^{25}+5\left(\mathrm{c} 0.12, \mathrm{CHCl}_{3}\right),\left(\right.$ lit., ${ }^{14}\left((R)\right.$-isomer, $56 \%$ ee; $\left.[\alpha]_{\mathrm{D}}+4.0\left(\mathrm{c} 1.0, \mathrm{CHCl}_{3}\right)\right)$. IR (neat) 2986, 2928, 1724, 1603, 1584, 1452, 1372, 1315, 1275, 1218, 1176, 1158, 1070, 1027, 976, 847, 712 $\mathrm{cm}^{-1} . \quad{ }^{1} \mathrm{H} \mathrm{NMR}\left(\mathrm{CDCl}_{3}\right) \delta=1.40(3 \mathrm{H}, \mathrm{s}), 1.47(3 \mathrm{H}, \mathrm{s}), 3.89(1 \mathrm{H}, \mathrm{dd}, J=8.29,5.86 \mathrm{~Hz}), 4.15(1 \mathrm{H}, \mathrm{dd}, J$ $=8.29,6.34 \mathrm{~Hz}), 4.38(1 \mathrm{H}, \mathrm{dd}, J=11.47,5.61 \mathrm{~Hz}), 4.41(1 \mathrm{H}, \mathrm{dd}, J=11.47,4.64 \mathrm{~Hz}), 4.42-4.50(1 \mathrm{H}, \mathrm{m})$, 7.43-7.48 (2H, m), 7.55-7.59 (1H, m), 8.05-8.07 (2H, m).

\section{$((1 R, 4 S)-3-P h e n y l-2-o x a-3-a z a b i c y c l o[2.2 .2]$ oct-7-en-1-yl)methyl}

(S)-N-(4-

Nitrophenylsulfonyl)phenylalanate: To a mixed solution of $6 \mathbf{a}$ (104 mg, $0.48 \mathrm{mmol}, 70 \%$ ee), triethylamine $(0.067 \mathrm{~mL}, 0.48 \mathrm{mmol})$ and a catalytic amount of DMAP in $\mathrm{CH}_{2} \mathrm{Cl}_{2}(5 \mathrm{~mL})$ was added $(S)$ $N$-(4-nitrophenylsulfonyl)phenylalanyl chloride $(178 \mathrm{mg}, 0.48 \mathrm{mmol})$ at $\mathrm{rt}$ under a nitrogen atmosphere. The resulting solution was kept at the same temperature for $3 \mathrm{~d}$ with stirring. The solvent was removed in vacuo and the residue was partitioned between EtOAc and water. The organic extracts were washed successively with water, brine and dried over $\mathrm{Na}_{2} \mathrm{SO}_{4}$. Evaporation of the solvent and separation of the 
residue by preparative TLC $\left(\mathrm{CH}_{3} \mathrm{Cl} / \mathrm{MeOH}=30 / 1\right.$, v/v) afforded the desired product $(186 \mathrm{mg}, 71 \%)$. A solid. IR $(\mathrm{KBr})=3105,3057,2927,2849,1739,1596,1529,1487,1455,1435,1349$, 1312, 1239, 1166 , 1092, 1029, 974, 916, 853, 764, 737, 703, $685 \mathrm{~cm}^{-1} . \quad{ }^{1} \mathrm{H}$ NMR $\left(\mathrm{CDCl}_{3}\right) \delta=1.24(1 \mathrm{H}, \mathrm{m}), 1.63(1 \mathrm{H}, \mathrm{ddd}$, $J=12.93,6.34,3.17 \mathrm{~Hz}), 1.96(1 \mathrm{H}, \mathrm{dddd}, J=12.69,9.27,6.59,3.17 \mathrm{~Hz}), 2.35(1 \mathrm{H}, \mathrm{dddd}, J=12.69,6.34$, 3.66, $2.20 \mathrm{~Hz}), 3.05(1 \mathrm{H}, \mathrm{dd}, J=13.91,7.32 \mathrm{~Hz}), 3.19(1 \mathrm{H}, \mathrm{dd}, J=13.91,5.12 \mathrm{~Hz}), 4.19(1 \mathrm{H}, \mathrm{d}, J=$ $11.95 \mathrm{~Hz}), 4.35(1 \mathrm{H}, \mathrm{ddd}, J=9.27,7.32,5.12 \mathrm{~Hz}), 4.44(1 \mathrm{H}, \mathrm{d}, J=11.95 \mathrm{~Hz}), 4.48(1 \mathrm{H}, \mathrm{m}), 5.55(1 \mathrm{H}, \mathrm{d}$, $J=9.27 \mathrm{~Hz}), 6.14(1 \mathrm{H}, \mathrm{dd}, J=8.29,5.61 \mathrm{~Hz}), 6.20(1 \mathrm{H}, \mathrm{d}, J=8.29 \mathrm{~Hz}), 6.92-6.99$ (3H, m), 7.06-7.08 $(2 \mathrm{H}, \mathrm{m}), 7.19-7.25(5 \mathrm{H}, \mathrm{m}), 7.79(2 \mathrm{H}, \mathrm{d}, J=8.78 \mathrm{~Hz}), 8.12(2 \mathrm{H}, \mathrm{d}, J=8.78 \mathrm{~Hz})$. Single crystal of 9.EtOAc was obtained by recrystallization from EtOAc. Mp 89-92 ${ }^{\circ} \mathrm{C}$ (from EtOAc). Found: C, 60.29; H, 5.54; N, 6.53\%. Calcd for $\mathrm{C}_{32} \mathrm{H}_{35} \mathrm{~N}_{3} \mathrm{O}_{9} \mathrm{~S}: \mathrm{C}, 60.27 ; \mathrm{H}, 5.53 ; \mathrm{N}, 6.59 \%$. Crystal data: $\mathrm{C}_{32} \mathrm{H}_{35} \mathrm{~N}_{3} \mathrm{O}_{9} \mathrm{~S}, F W 637.70$, orthorhombic, $P 2_{1} 2_{1} 2_{1}, a=8.568(2) \AA, b=11.395(3) \AA ⿻$ А $c=31.586(9) \AA, V=$ 3083(1) $\AA^{3}, Z=4 . \quad D_{\text {calc }}=1.373 \mathrm{~g} / \mathrm{cm}^{3} . \quad R=0.048\left(R_{w}=0.059\right)$ for 3338 reflections with $I>3.00 \sigma(I)$ and 406 variable parameters.

\section{ACKNOWLEDGEMENTS}

The present work was financially supported in part by a Grant-in-Aid for Scientific Research on Priority Areas “Advanced Molecular Transformations of Carbon Resources” from The Ministry of Education, Culture, Sports, Science and Technology (MEXT), a Grant-in-Aid for Scientific Research from Japan Society for the Promotion of Science (JSPS), and the Asahi Glass Foundation.

Dedicated to Professor Ryoji Noyori on the occasion of his 70th birthday.

\section{REFERENCES AND NOTES}

1. L. F. Tietze and G. Kettschau, 'Topics in Current Chemistry,' 1997, 189, 1; M. D. Bednarski and J. P. Lyssikatos, 'Comprehensive Organic Synthesis,' Vol. 2, ed. by B. M. Trost and I. Fleming, Pergamon Press, New York, 1991, p. 661; D. L. Boger and S. M. Weinreb, 'Hetero Diels-Alder Methodology in Organic Synthesis,' Academic Press, Inc., San Diego, 1987; S. M. Weinreb and R. R. Staib, Tetrahedron, 1982, 38, 3087.

2. P. F. Vogt and M. J. Miller, Tetrahedron, 1998, 54, 1317; C. Kibayashi and S. Aoyagi, Synlett, 1995, 873; J. Streith and A. Defoin, Synthesis, 1994, 1107.

3. H. Yamamoto and M. Kawasaki, Bull. Chem. Soc. Jpn., 2007, 80, 595; H. Yamamoto and N. Momiyama, Chem. Commun., 2005, 3514.

4. Y. Yamamoto and H. Yamamoto, Angew. Chem. Int. Ed., 2005, 44, 7082; Y. Yamamoto and H. 
Yamamoto, J. Am. Chem. Soc., 2004, 126, 4128.

5. C. P. Chow and K. J. Shea, J. Am. Chem. Soc., 2005, 127, 3678.

6. Although an enantioselective hetero Diels-Alder reaction of a nitroso compound promoted by an antibody was reported, the enantioselectivity was not sufficient; A. A. P. Meekel, M. Resmini, and U. K. Pandit, Bioorg. Med. Chem., 4, 1051 (1996).

7. Related nitroso Diels-Alder-type ring formation: N. Momiyama, Y. Yamamoto, and H. Yamamoto, $J$. Am. Chem. Soc., 2007, 129, 1190.

8. A sequential method to access chiral 1,2-oxazines by an asymmetric $\alpha$-oxyamination of carbonyl compounds and conjugate addition to vinylphosphonium salts, followed by an intramolecular Wittig reaction was reported: a) S. Kumarn, D. M. Shaw, D. A. Longbottom, and S. V. Ley, Org. Lett., 2005, 7, 4189; b) S. Kumarn, D. M. Shaw, and S. V. Ley, Chem. Commun., 2006, 3211; c) S. Kumarn, A. J. Oelke, D. M. Shaw, D. A. Longbottom, and S. V. Ley, Org. Biomol. Chem., 2007, 5, 2678.

9. Y. Ukaji and K. Inomata, Synlett, 2003, 1075.

10. A similar strategy was already found to be effective for an asymmetric Diels-Alder reaction of $o$ quinodimethanes: M. Takinami, Y. Ukaji, and K. Inomata, Tetrahedron: Asymmetry, 2006, 17, 1554.

11. Preliminary results have been reported: D. Xia, Y. Ukaji, S. Fujinami, and K. Inomata, Chem. Lett., $2003,32,582$.

12. The previous assignment of absolute stereochemistry of $\mathbf{3}^{11}$ was incorrect and should be corrected as described in this manuscript.

13. P. Zuman and B. Shah, Chem. Rev., 1994, 94, 1621.

14. D. Terakado, H. Koutaka, and T. Oriyama, Tetrahedron: Asymmetry, 2005, 16, 1157.

15. J. A. Sousa and A. L. Bluhm, J. Org, Chem., 1960, 25, 108. 